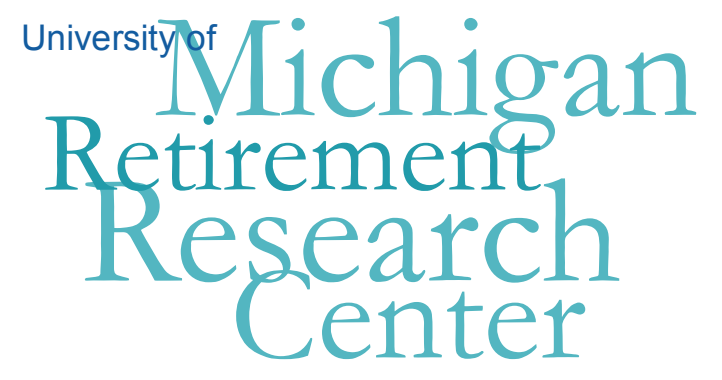

Working Paper

WP 2010-242

\title{
Post-Retirement Adjustments in Defined Benefit Pensions
}

Charles Brown

\begin{tabular}{|l|l|}
\hline $\mathrm{M}$ & $\mathrm{R}$ \\
\hline $\mathrm{R}$ & $\mathrm{C}$ \\
\hline
\end{tabular}

Project \#: UM10-17 


\title{
Post-Retirement Adjustments in Defined Benefit Pensions
}

\author{
Charles Brown \\ University of Michigan and NBER
}

December 2010

\author{
Michigan Retirement Research Center \\ University of Michigan \\ P.O. Box 1248 \\ Ann Arbor, MI 48104 \\ http://www.mrrc.isr.umich.edu/ \\ (734) 615-0422
}

\section{Acknowledgements}

This work was supported by a grant from the Social Security Administration through the Michigan Retirement Research Center (Grant \# 10-M-98362-5-01). The findings and conclusions expressed are solely those of the author and do not represent the views of the Social Security Administration, any agency of the Federal government, or the Michigan Retirement Research Center.

\section{Regents of the University of Michigan}

Julia Donovan Darrow, Ann Arbor; Laurence B. Deitch, Bingham Farms; Denise Ilitch, Bingham Farms; Olivia P. Maynard, Goodrich; Andrea Fischer Newman, Ann Arbor; Andrew C. Richner, Grosse Pointe Park; S. Martin Taylor, Gross Pointe Farms; Katherine E. White, Ann Arbor; Mary Sue Coleman, ex officio 


\title{
Post-Retirement Adjustments in Defined Benefit Pensions
}

\author{
Abstract \\ Few private defined benefit pension plans commit to indexing benefits after a worker begins \\ receiving them. Previous (now dated) research found that most plans did, nonetheless, make \\ "voluntary" adjustments, which compensated for roughly 40 percent of the price increases \\ experienced since retirement. In analyzing changes in pension benefits reported by HRS \\ respondents between 1994 and 2008, I find annual increases that are about one third of the \\ increase in the CPI. The increases are concentrated among respondents who report that their \\ benefits are adjusted for inflation. They are larger for workers in public administration than in \\ other industries; perhaps surprisingly, they are not larger in jobs covered by union contracts than \\ those in the non-union sector. The HRS data also show that benefits paid out of defined \\ contribution plans increased, again by roughly one third of the increase in consumer \\ prices.Authors' Acknowledgements
}


A member of the original HRS cohort who retired at about the time of her first interview at age 62 would now be 80 years old. Her Social Security benefit would have increased just over $50 \%$ in nominal terms, keeping its real value constant. If she retired with a defined benefit (DB) pension that was indexed to the CPI, her monthly pension check would now be $50 \%$ larger, too. But most DB pensions are not formally linked to the CPI, or any other index. If her nominal benefits were not adjusted at all, her pension check would now be worth about two thirds of its value in 1992.

Inflation matters for present values as well as for annual benefits, though the growing impact of inflation is offset by declining probabilities of surviving to experience such misfortune. Nevertheless, for a single worker retiring at age 62 , with a $2.9 \%$ real interest rate and a modest 2.8\% rate of inflation (Board of Trustees (2009)), indexing increases the expected present value of benefits received by $21 \%$ for men and $23 \%$ for women.

Understanding how such adjustments are made - or are not made - using data from the actual experiences of HRS respondents will allow researchers to assess whether the substantial cumulative effects of even moderate inflation rates are being realized or offset.

\section{Previous Research}

Some DB pensions - mostly in the public sector - are indexed to the CPI, and many others are adjusted even though the employer has no legal obligation to do so. Allen, Clark, and Sumner $(1984,1986)$ studied post-retirement benefit increases for a sample of DB plans weighted to be representative of private DB plans. Increases were legally required in "almost none” of the plans; nevertheless, between 1973 and 1979, 74.6 percent of retirees received at 
least one benefit adjustment, though only 24.5 percent received an increase each year. Overall, benefits of sample members increased by 24 percent, which was about 40 percent of the CPI increase over the period. Collectively bargained plans were about twice as likely as non-union plans to provide increases. ACS conclude that "the private pension system was much more responsive during the 1970s inflation than was previously believed.”

In a later paper, Allen, Clark, and McDermed (1992) found that, in a sample of medium and large firms, the fraction of workers in plans making any post-retirement adjustments fell from 51 (1978-82) to 22 percent (1984-88). The fraction of CPI inflation offset by benefit adjustments was 10-30 percent, depending on starting and ending date. While the difference in samples makes exact comparisons difficult, the frequency of adjustments and the fraction of inflation offset appear lower than a decade earlier. Gustman and Steinmeier (1993a), in contrast, found that pension recipients in PSID saw adjustments that were about half of the CPI increase in both 1971-79 and 1979-87. Mitchell (1999) reported that frequency of adjustments continued to decline through the mid-1990s, but did not calculate the size of those adjustments.

Government pensions are more likely to be adjusted after retirement and to be formally indexed to inflation (Weinstein, 1997). But these adjustments compensated for only a fraction of inflation (Phillips, 1992), as caps result in less than full inflation protection.

With lower inflation rates since the inception of HRS, one might guess that the frequency of inflation adjustments has probably fallen, but there is no hard evidence available. Unfortunately, this does not mean that the effect of inflation on pension wealth and retirement income adequacy can be ignored. As shown above, as life expectancies increase, the capacity of even modest inflation to erode the value of pension benefits is substantial. 
Given the patchy evidence discussed so far, one might wonder what assumptions analysts make when calculating pension wealth - i.e., the present value of future benefit flows. Often, it is hard to tell. But in papers where the issue is explicitly addressed, either relying on the ACS estimate (e.g., Gustman and Steinmeier, 1993 and 2000; Evan and McPherson, 2007), or ignoring such adjustments altogether (Mehdizadeh and Luzadis, 1994; Samwick, 1998) seem to be the most common alternatives.

\section{Data}

The data for this study are taken from the Health and Retirement Study. The HRS began as a longitudinal study of those who were 51 to 61 in 1992 (i.e., the 1931-41 birth cohorts) and their spouses regardless of age. In 1993, the Aging and Health Dynamics (AHEAD) study first interviewed a sample of those born before 1923; in 1998 the AHEAD sample as well as samples of those born in 1923-1930, and 1942-47 were added - at which point HRS included all those age 51 or older. In 2004, those born in 1948-54 - i.e., those who had turned 51 since 1998 were added.

The key variable of interest is the amount received from pension plans other than Social Security or Veterans pensions. The question sequence from HRS 2008 is included as Appendix A, with minor changes this sequence has been used since 1994 (the 1992 HRS and 1983 AHEAD waves were much different and are not included in this paper). If the respondents are married, the information is obtained, for both partners, from the financially knowledgeable respondent. For simplicity, I will focus on the "version" of the question that is used in singleperson households (or in asking the financially knowledgeable respondent about his/her own pension). The interviewer first asks "Not including Social Security or other retirement income 
you've already told me about, are you [or your] [husband/wife/partner] currently receiving any other income from retirement pensions?” If the answer is affirmative, the interviewer asks whether our respondent, his/her spouse, or both are receiving pension income, and from how many pension plans. For each respondent, a sequence of questions is then asked about up to two (if more than two, the two most important) plans. For our purposes, the most important question is "How much did you receive last month from that pension, (before taxes and other deductions)?" We focus on the "most important" plan for respondents receiving benefits from more than one, though these respondents account for only about 10 percent of the sample.

One complication is that those receiving benefits from either a DB or a DC plan can answer this pension sequence. While our primary interest is in payments from DB plans, we will present results for both DB and DC benefits. The difficulties that respondents have in understanding and/or explaining basic features of their pensions (Gustman and Steinmeier, 2004; Chan and Stevens, 2008) will make it difficult to isolate DB plans with complete precision.

\section{Biennial Changes in Pension Benefits}

Given that HRS is conducted in even-numbered years (except for the pre-1998 AHEAD interviews) and asks only about current pension benefits, the most frequent changes we can track are those that occur between waves - i.e., over roughly two-year periods. In Table 1, we present summary statistics for such changes, weighted by the end-year sample weight. At the top of each column, we identify the years over which the change is computed, and, for reference, the proportional change in the CPI for those years. In the top panel, we include all pairs of years for which positive pension benefits are reported. The pension changes average about two 
percent across all year-pairs in the table, while the SSA CPI-driven adjustments average 5.4 percent, but there is quite a bit of variation from column to column, and the first two values are implausible. While we expect the true adjustments are a combination of zeros (when benefits are not adjusted) and a few percent (when they are) the standard deviations of the changes are much larger than a back-of-envelope calculation would expect.

The large standard deviations and occasionally implausible means raise concerns about the importance of outliers in the data. Ordinarily, concern about outliers would lead one to focus on medians as well as (or perhaps instead of) means. However, the median wave-to-wave change in pension benefits in our data is almost always zero - a reflection of the fact that true changes are small and respondents' rounding of monthly amounts. An alternative is to simply eliminate extreme outliers. In the second panel, we eliminate cases where reported benefits more than doubled, or fell by more than half (i.e., cases where $\mid \Delta \ln$ benefit $\mid>\ln (2)$. This has a small effect on the sample size - typically we lose 4-5 percent of the observations - but the sample standard deviations are only a half to a third as large. Tightening our criteria further, by excluding cases where $\mid \Delta \ln$ monthly benefit $\mid>\ln (1.5)$ brings the mean for 1994-1996 to a more plausible value (.015) but has virtually no effect for other years.

A slightly different strategy for dealing with outliers is to delete a fixed percentage of the observations from each tail of the distribution of reported values. In the third panel of Table 1, we show the results when 5 percent of the observations are deleted from each tail. This increases the reported adjustments very slightly (the mean adjustment across all pairs of adjacent interviews rises to 2.2 percent). 
Deleting changes in cases where respondents reported more than one benefit in one or both years also made almost no difference, as can be seen from the bottom three panels of Table 1. This should not be surprising, as the deleted cases are only about 10 percent of the sample.

While we have no good way to validate the reported values, we can conduct a very similar analysis for Social Security benefits, where the annual adjustments mirror December to December CPI changes, and so true changes are "known." ${ }^{1}$ In Table 2, wave-to-wave changes in Social Security benefits are reported, for those receiving them. Several patterns that were evident in the analysis of private pension benefits re-appear: the sample standard deviations for the full samples are quite large, and are dramatically reduced by eliminating a handful of outliers. Still, there is considerable variability across respondents for a variable for which we are confident true changes are the same for a substantial majority. Looking across all the columns of the table, in the first panel reported increases average 4.9 percent while the CPI-based increases average 5.4 percent. Eliminating outliers reduces the average reported increase to 4.7 percent. Table 2 thus confirms that changes in individual reports of Social Security benefits are noisy, but on average seem accurate.

Suppose that reports of pension benefits are about as accurate as reports of Social Security benefits, and all of the reported variation in the latter is error. In this case, comparing the sample variances of the two variables suggests that 50-60 percent of the reported variation in pension benefits is measurement error, and the remaining 40 percent is true variation.

\footnotetext{
${ }^{1}$ A few changes in an individual's Social Security benefits will be due to other factors. For example, a widow or widower may be entitled to survivor's benefits based on their his or her spouse's earnings records, resulting in a one-time increase that would exceed the CPI change. Alternatively, an individual whose benefits are reduced because of earnings will have benefit changes that depend on changes in earnings as well as changes in the CPI.
} 


\section{Changes Over the HRS Sample Period}

A standard response to the noisiness of "change" measures in survey data is to focus on changes over a longer period of time. This allows for greater variability in the true value or "signal”, while (on reasonable assumptions) not increasing the measurement error or "noise". One complication in applying this idea to HRS pension recipients is that the time period spanned by the respondent's first and last (as of 2008 interview) benefit varies across respondents. In response, we focus on the average annual increase, computed as

$$
\frac{\Delta \ln (\text { pension })}{\Delta \ln \text { years }} \equiv \frac{\ln (\text { last pension benefit })-\ln (\text { first pension benefit })}{\text { number of years between first and last wave with positive pension benefits }}
$$

For the full sample, the average annual adjustment is .014 (1.4 percent), while the average annual increase in CPI over the same period is .0256, so the effective indexing ratio (= benefit adjustment divided by CPI increase) is .54. Thus, benefit adjustments are roughly half of what one would observe if benefits were completely indexed. ${ }^{2}$ If we eliminate observations for which $\mid \Delta \ln ($ pension $) \mid$ is greater than 2 , the average annual benefit increase is .008 , and the "effective indexing ratio" is .32. Deleting five percent of values in each tail of the distribution gave an average adjustment of .014 (the full sample value), while the other outlier deletion rules in produced estimates closer to .008 .

All of the results so far refer to all respondents who report a monthly benefit from an employer-sponsored pension plan. However, for many purposes we are interested in the extent of inflation adjustments for defined benefit plans. Under a DC plan, the monthly payout can be structured in various ways, but the present value of the benefits is equal to the value of the assets

\footnotetext{
${ }^{2}$ The CPI increase that corresponds to a particular pension benefit adjustment varies from observation to observation, and so the mean CPI increase, which is the denominator of the effective indexing ratio, varies slightly from cell to cell in Table 3.
} 
in the DC account, regardless of how payouts are specified. For DB plans, in contrast, benefit adjustments represent real increases in pension wealth. Thus, it would be useful to calculate the inflation adjustments for DB and DC plans separately.

Unfortunately, many pension plan participants apparently do not understand enough about their plans to accurately distinguish DB from DC plans (Gustman and Steinmeier, 2004; Chan and Stevens, 2008), so several approaches to the problem of identifying respondents whose pension benefits come from DB plans will be considered. In each wave, respondents currently receiving pension benefits are asked several questions about their benefits which provide indirect evidence on the $\mathrm{DB} / \mathrm{DC}$ issue:

"If you wanted to, could you choose to receive a larger or smaller amount from that pension next month?”

"Could you withdraw some or all of the money from that pension plan this month?” Both of these questions should be answered "No" by those with DB plans; unless they have annuitized their benefits (annuities are covered elsewhere in the survey) they should be able to vary payouts or take a lump-sum payment from a DC plan. Consistent with the importance of DB plans among those receiving benefits in the HRS age cohorts, the strong majority of those receiving benefits answer "No" to both questions in each survey year. On the other hand, respondents may not realize that they have these options, or may learn about them at some point after beginning benefits. Thus, any respondent who ever answers yes to either question is treated as a likely DC recipient, and any who consistently answer "No" to both questions in all waves are treated as likely DB recipients. Perhaps surprisingly, dividing recipients in this way leads to almost identical increases in annual benefits for the two groups, which again is slightly smaller if 
one eliminates outliers. However, there are relatively few pension recipients in these age cohorts who appear to be receiving DC pensions.

Another plan characteristic of interest is whether the benefits are automatically adjusted for inflation. Those currently receiving benefits are asked:

Is the pension payment automatically adjusted for changes in the cost of living?

In Table 3, respondents are divided into three groups: those who answer "No" in both the first and last year in which they report benefits, those who answer "Yes" in both years, and those who answer "Yes" in one of these two years. Annual benefit adjustments are larger for those who report automatic increases. But there are two surprises. First, adjustments are essentially zero for those who do not report having automatic adjustments, while adjustments for those who report such adjustments to be automatic are substantial. Second, the fraction of the sample reporting automatic adjustments is higher than we should be getting if respondents are telling us about what is mandated by their plan. ${ }^{3}$ Instead, they appear to be responding "yes" for both mandated and "voluntary” increases. While it is reassuring that those who report their benefits are adjusted do, in fact, report larger adjustments, it does not appear that respondents are equating “automatic” with "mandated by the plan’s provisions.”

\section{Matching Pension Benefits to Prior Jobs}

When respondents report receiving benefits, these benefits are not automatically linked to a specific employer. However, respondents are asked when they first received benefits, and their responses provide a strong clue as to which job(s) might have generated the benefits in question.

\footnotetext{
${ }^{3}$ Weinstein (1997) reports that about half of state and local government DB participants were in plans that provided for automatic benefit adjustments, but this fraction was only about 4 percent in the private sector.
} 
HRS asks new respondents who are working for pay about their current job, and those who are not working about their last job. In addition, those who held previous jobs lasting five or more years are asked about whether they participated in a pension on that job, and relevant details are collected. Each later wave collects information about the currently-held job.

We apply two "rules" for matching the pension benefits reported in the income section to a specific previous job from the employment section. First, identify those jobs at which respondent reported participating in a pension plan that ended no later than the year in which pension benefits began. If there is more than one such job, one rule selects the "longest” such job, while the other selects the "last" such job (typically, the one that ended in the year that benefits began). Fortunately, in just over 90 percent of all cases, the "last" and "longest” jobs were the same. Table 4 focuses on characteristics of the job based on the "longest" job rule.

The first line of Table 4 shows the post-retirement adjustments for workers whose pensions could be successfully matched to a prior job. The 1993 and 1995 waves of AHEAD that were conducted separately from HRS did not ask about pension coverage on these jobs, so the pensions matched to prior jobs are coming from the HRS and not the AHEAD birth cohort. Comparing the first line of Table 4 (pensions matched to jobs) to the first line of Table 3 (all pensions) shows somewhat smaller benefit increases for the jobs we can match, though this difference is fairly small when outliers are removed.

The next section of Table 4 compares adjustments of DB and DC recipients, basing this distinction on the respondent's characterization of the plan in the first interview after leaving that job. One might hope that details of the pension plan would be particularly salient then. Once again, the strong majority of those reporting pension benefits appear be drawing on DB plans, but there is very little difference in the adjustment of DB and DC benefits. 
The third section of the table divides respondents into three broad industry groupings manufacturing, public administration (which, unfortunately, is only a subset of public sector workers), and "other". There is no evidence of adjustments in manufacturing, while there are substantial adjustments in public administration, and smaller but still significant adjustments in the residual industrial category.

Another job characteristic that is often associated with high levels of pension coverage and more generous benefits is coverage by a collective bargaining agreement. In Table 4, however, we find no evidence of greater post-retirement adjustment in the pension benefits of those covered by union contracts. ${ }^{4}$

\section{Matching Pension Benefits to Prior Jobs}

HRS attempted to obtain the Summary Plan Descriptions for respondents' pension plans and code the provisions of these plans in a data base. Almost all of the effort focused on jobs identified in 1992, 1998, and 2004, years in which new birth cohorts were brought into the sample. In 1992 and 1998, HRS attempted to obtain SPDs for both current and previous jobs on which the respondent had a pension; in 2004 only current jobs were pursued. Given that very few current jobs in 2004 would have led to two waves of pension benefit receipt by 2008 (the minimal requirement for calculating any benefit adjustment), we focused on the 1992 and 1998 SPD coding efforts.

Having identified a job as the job likely responsible for the pension benefit that is being received, we then "looked up" that job in the file with pension plan provisions. If a match was

\footnotetext{
${ }^{4}$ HRS obtains union status information for jobs held at or after the baseline interview and for the most recent job held for those who are not employed at baseline, but not for earlier jobs. This results in a smaller sample size, and accounts for the slightly smaller mean adjustments for both union and non-union jobs compared to the larger sample of all matched jobs on the first line of Table 4.
} 
obtained, the summary plan description's characterization of the plan as DB or DC was retained. $^{5}$

The last panel in Table 4 shows the benefit adjustment information for plans characterized as DB or DC based on the SPD information. The DB-DC distinction is more accurate here than elsewhere, as it is based on actual plan documents. Unfortunately, HRS was less successful in obtaining these documents for "past" jobs (which are likely to be DB) than for jobs that were in progress at time of interview; on the other hand, public sector employers were more cooperative, which would tend to increase the fraction of matched plans that are DB. In any case, the DB majority is smaller among the matched plans. But, once again, adjustments are very similar for DB and DC plans.

\section{Conclusions}

The benefit adjustments in this study are based on taking log-differences of the monthly benefits reported by HRS respondents in each biennial interview. As is often true of survey reports of income (or wealth) components, data that appear reasonable when one focuses on "levels" are much more noisy when expressed as first differences. Nonetheless, we can estimate mean adjustments with reasonable precision, particularly if we eliminate extreme outliers.

Post-retirement benefit adjustments experienced by HRS respondents averaged roughly a third of the corresponding increase in the CPI. Because DB pensions are still the dominant type of pension for these cohorts of workers, and because DC plans appear to have similar-sized adjustments, the one-third estimate is likely close to the mark for DB plans -- and this estimate

\footnotetext{
${ }^{5}$ If there was more than one matched plan, the benefits were coded as DB if any of the matched plans were DB plans (e.g., a DB and a supplemental DC).
} 
finds support for the subset of pensions we could link to DB/DC information based on summary plan descriptions. Adjustments are largest in public administration, negligible in manufacturing, and modest but non-zero in other industries. They are very similar in union and non-union sectors.

The importance of "mandatory" vs. "voluntary" adjustment is harder to assess. Nearly all of the adjustments occur in pensions that respondents say are "automatically" adjusted for inflation, but there are too many reporting "automatic" adjustment for this to be taken as a synonym for "mandated" adjustment. With a third to a half of respondents reporting such adjustments, and as actual adjustments were detectable for these respondents, it seems clear that post-retirement adjustments continued in the low-inflation environment of the past two decades. To be sure, the adjustments do not fully compensate for inflation, even for the respondents who report receiving them. On the other hand, they are larger than might have been expected given that adjustments typically become less common when inflation is low (Weinstein, 1997) and that many employers are struggling to even fund the benefits that are legally required under their plans. 


\section{References}

Allen, Steven G.; Clark, Robert L.; and McDermed, Ann A. "Post-Retirement Increases in the 1980s," in John Turner and Daniel Beller (eds.), Trends in Pensions 1992, Washington, DC: USGPO, 1992, pp. 319-339

Allen, Steven G.; Clark, Robert L.; and Sumner, Daniel A. "A Comparison of Pension Benefit Increases and Inflation," Monthly Labor Review, May 1984, pp. 42-46.

Allen, Steven G.; Clark, Robert L.; and Sumner, Daniel A. "Post-Retirement Adjustments of Pension Benefits," Journal of Human Resources, Winter 1986, pp. 118-137

Board of Trustees, Federal Old-Age and Survivors Insurance and Federal Disability Trust Funds. The 2009 Annual Report of Trustees, Federal Old-Age and Survivors Insurance and Federal Disability Trust Funds, May 2009. http://ssa.gov/OACT/TR/2009/tr09.pdf

Chan, Sewin and Stevens, Ann Huff. “What You Don’t Know Can’t Help You: Pension Knowledge and Retirement Decision-Making,” Review of Economics and Statistics, May 2008, pp. 253-266.

Even, William and MacPherson, David. “ Defined Contribution Plans and the Distribution of Pension Wealth, Industrial Relations, July 2007, pp. 551-581.

Gustman, Alan L. and Steinmeier, Thomas L. "Pension Portability and Labor Mobility Evidence from the Survey of Income and Program Participation,” Journal of Public Economics, March 1993a, pp. 299-323. 
Gustman, Alan L. and Steinmeier, Thomas L. "Cost of Living Adjustments in Pensions," in Olivia S. Mitchell, ed., As the Workforce Ages: Costs, Benefits and Policy Challenges, Ithaca, New York: ILR Press, 1993b, pp. 147-180.

Gustman, Alan L. and Steinmeier, Thomas L. "Retirement in Dual-career Families: A Structural Model, Journal of Labor Economics, July 2000, pp. 503-545.

Gustman, Alan L. and Steinmeier, Thomas L. “What People Don’t Know about Their Pensions and Social Security,” in William G. Gale, John B. Shoven, and Mark J. Warshawsky (Eds.), Private Pensions and Public Policies (Washington, DC: Brookings Institution, 2004).

Mehdizadeh, Shahla A. and Luzadis, Rebecca A., “The Effect of Job Mobility on Pension Wealth,” Gerontologist, April 1994, pp. 173-179.

Mitchell, Olivia. "New Trends in Pension Benefit and Retirement Provisions,” NBER Working Paper 7381, October 1999.

Phillips, Kristen. "State and Local Government Pension Benefits,” in John Turner and Daniel Beller (eds.), Trends in Pensions 1992, Washington, DC: USGPO, 1992, pp. 341-392.

Samwick, Andrew. "New Evidence on Pensions, Social Security, and the Timing of Retirement.” Journal of Public Economics, November 1998, pp. 207-236.

Stolyarova, Helena; Nolte, Michael; and Peticolas, Bob. "Pension Estimation Program Users Guide,” December 2008. http://hrsonline.isr.umich.edu/sitedocs/pep/PenCalcUser2008.pdf

Weinstein, Harriet. “Post-retirement Pension Increases,” Compensation and Working Conditions, Fall 1997, pp. 47-50. 
Table 1

Wave-to Wave Changes in Monthly Private Pension Benefits ( $\Delta \ln$ monthly benefit)

\begin{tabular}{|c|c|c|c|c|c|c|c|c|c|}
\hline & & $\begin{array}{l}\text { 1994- } \\
1996 \\
\text { HRS }\end{array}$ & $\begin{array}{c}\text { 1995- } \\
1998 \\
\text { AHEAD }\end{array}$ & $\begin{array}{c}1996- \\
1998 \\
\text { All }\end{array}$ & $\begin{array}{c}1998- \\
2000 \\
\text { All }\end{array}$ & $\begin{array}{c}2000- \\
2002 \\
\text { All }\end{array}$ & $\begin{array}{c}2002- \\
2004 \\
\text { All }\end{array}$ & $\begin{array}{c}2004- \\
2006 \\
\text { All }\end{array}$ & $\begin{array}{c}2006- \\
2008 \\
\text { All }\end{array}$ \\
\hline Social Security COLA & & 0.053 & 0.075 & 0.049 & 0.038 & 0.060 & 0.035 & 0.067 & 0.055 \\
\hline \multirow[t]{4}{*}{ All Observations } & Mean & -0.056 & 0.074 & 0.041 & 0.016 & 0.029 & 0.021 & 0.003 & 0.025 \\
\hline & Std.err. & 0.021 & 0.015 & 0.009 & 0.006 & 0.007 & 0.009 & 0.010 & 0.011 \\
\hline & Std.dev. & 0.574 & 0.413 & 0.305 & 0.359 & 0.384 & 0.494 & 0.498 & 0.546 \\
\hline & $\mathrm{N}$ & 736 & 722 & 1214 & 3099 & 2952 & 2760 & 2727 & 2457 \\
\hline \multirow[t]{4}{*}{ Delete $\mid \Delta \ln$ pension $\mid>2$} & Mean & -0.003 & 0.043 & 0.035 & 0.017 & 0.027 & 0.016 & 0.013 & 0.011 \\
\hline & Std.err. & 0.007 & 0.006 & 0.005 & 0.003 & 0.003 & 0.003 & 0.003 & 0.003 \\
\hline & Std.dev. & 0.184 & 0.160 & 0.161 & 0.156 & 0.168 & 0.158 & 0.160 & 0.159 \\
\hline & $\mathrm{N}$ & 682 & 675 & 1176 & 2976 & 2814 & 2636 & 2612 & 2353 \\
\hline Delete $5 \%$ of sample & Mean & -0.014 & 0.058 & 0.037 & 0.018 & 0.030 & 0.020 & 0.011 & 0.015 \\
\hline \multirow[t]{3}{*}{ from each tail } & Std.err. & 0.006 & 0.006 & 0.003 & 0.002 & 0.002 & 0.002 & 0.002 & 0.002 \\
\hline & Std.dev. & 0.166 & 0.139 & 0.106 & 0.104 & 0.120 & 0.113 & 0.112 & 0.106 \\
\hline & $\mathrm{N}$ & 663 & 651 & 1092 & 2773 & 2659 & 2490 & 2445 & 2276 \\
\hline \multirow[t]{4}{*}{ Only one pension } & Mean & -0.061 & 0.078 & 0.046 & 0.015 & 0.030 & 0.021 & 0.006 & 0.026 \\
\hline & Std.err. & 0.022 & 0.016 & 0.009 & 0.007 & 0.007 & 0.010 & 0.010 & 0.012 \\
\hline & Std.dev. & 0.584 & 0.419 & 0.305 & 0.360 & 0.376 & 0.487 & 0.495 & 0.545 \\
\hline & $\mathrm{N}$ & 705 & 677 & 1135 & 2858 & 2705 & 2509 & 2444 & 2234 \\
\hline Only one pension. & Mean & -0.004 & 0.045 & 0.037 & 0.015 & 0.029 & 0.017 & 0.013 & 0.010 \\
\hline \multirow[t]{3}{*}{ Delete $\mid \Delta \ln$ pension $\mid>2$} & Std.err. & 0.007 & 0.006 & 0.005 & 0.003 & 0.003 & 0.003 & 0.003 & 0.003 \\
\hline & Std.dev. & 0.183 & 0.160 & 0.157 & 0.154 & 0.164 & 0.156 & 0.159 & 0.157 \\
\hline & $\mathrm{N}$ & 654 & 633 & 1099 & 2741 & 2580 & 2397 & 2341 & 2149 \\
\hline Only one pension, & Mean & -0.014 & 0.058 & 0.037 & 0.018 & 0.030 & 0.020 & 0.011 & 0.015 \\
\hline Delete $5 \%$ of sample & Std.err. & 0.006 & 0.006 & 0.003 & 0.002 & 0.002 & 0.002 & 0.002 & 0.002 \\
\hline \multirow[t]{2}{*}{ from each tail } & Std.dev. & 0.166 & 0.139 & 0.106 & 0.104 & 0.120 & 0.113 & 0.112 & 0.106 \\
\hline & $\mathrm{N}$ & 663 & 651 & 1092 & 2773 & 2659 & 2490 & 2445 & 2276 \\
\hline
\end{tabular}


Table 2

Wave-to Wave Changes in Monthly Social Security Benefits

( $\Delta$ ln monthly benefit)

\begin{tabular}{|l|l|r|r|r|r|r|r|r|r|}
\hline & & $\begin{array}{c}1994- \\
1996 \\
\text { HRS }\end{array}$ & $\begin{array}{c}1995- \\
\text { AHEAD }\end{array}$ & $\begin{array}{c}1996- \\
\text { All }\end{array}$ & $\begin{array}{c}1998- \\
\text { All }\end{array}$ & $\begin{array}{c}2000- \\
\text { All }\end{array}$ & $\begin{array}{c}2002- \\
\text { All }\end{array}$ & $\begin{array}{c}2004- \\
\text { All } \\
\text { All }\end{array}$ & $\begin{array}{c}2006- \\
2008 \\
\text { All }\end{array}$ \\
\hline Social Security COLA & & 0.053 & 0.075 & 0.049 & 0.038 & 0.060 & 0.035 & 0.067 & 0.055 \\
\hline All Observations & Mean & 0.035 & 0.103 & 0.039 & 0.035 & 0.064 & 0.025 & 0.034 & 0.059 \\
\hline & Std.err. & 0.031 & 0.010 & 0.010 & 0.005 & 0.006 & 0.006 & 0.006 & 0.008 \\
\hline & Std.dev. & 0.492 & 0.259 & 0.283 & 0.264 & 0.287 & 0.277 & 0.308 & 0.363 \\
\hline & N & 251 & 734 & 745 & 2694 & 2664 & 2568 & 2546 & 2353 \\
\hline Delete $\mid \Delta$ ln pension $>2$ & Mean & 0.059 & 0.086 & 0.034 & 0.040 & 0.053 & 0.027 & 0.031 & 0.047 \\
\hline & Std.err. & 0.009 & 0.005 & 0.004 & 0.002 & 0.002 & 0.003 & 0.003 & 0.003 \\
\hline & Std.dev. & 0.135 & 0.136 & 0.116 & 0.117 & 0.122 & 0.125 & 0.126 & 0.126 \\
\hline & N & 238 & 708 & 732 & 2635 & 2597 & 2504 & 2482 & 2292 \\
\hline Delete 5\% of sample & Mean & 0.052 & 0.090 & 0.036 & 0.037 & 0.056 & 0.026 & 0.035 & 0.048 \\
\hline from each tail & Std.err. & 0.006 & 0.004 & 0.002 & 0.001 & 0.001 & 0.001 & 0.001 & 0.002 \\
\hline & Std.dev. & 0.089 & 0.091 & 0.050 & 0.062 & 0.070 & 0.066 & 0.065 & 0.074 \\
\hline & N & 227 & 655 & 661 & 2403 & 2396 & 2300 & 2272 & 2117 \\
\hline
\end{tabular}


Table 3

"Long Differences"

Average Annual Increase between First and Last Pension Benefit

$(\Delta$ ln monthly benefit $) /(\Delta$ years $)$

by respondent reported benefit characteristics

\begin{tabular}{|c|c|c|c|c|c|c|c|c|c|}
\hline & & \multicolumn{4}{|c|}{ All observations } & \multicolumn{4}{|c|}{$\mid \Delta \ln ($ pension $) \mid>2$ excluded } \\
\hline & Group & $\begin{array}{c}\text { Mean of } \\
\frac{\Delta \ln \text { pension }}{\Delta \text { years }}\end{array}$ & $\begin{array}{l}\text { Std. } \\
\text { Error }\end{array}$ & $\mathrm{N}$ & $\begin{array}{l}\text { Effective } \\
\text { Indexing } \\
\text { ratio }\end{array}$ & $\begin{array}{c}\text { Mean of } \\
\frac{\Delta \ln \text { pension }}{\Delta \text { years }}\end{array}$ & $\begin{array}{l}\text { Std. } \\
\text { Error }\end{array}$ & $\mathrm{N}$ & $\begin{array}{l}\text { Effective } \\
\text { Indexing } \\
\text { ratio }\end{array}$ \\
\hline All Pensions & & 0.014 & 0.002 & 6604 & 0.535 & 0.008 & 0.001 & 5825 & 0.324 \\
\hline By pension type $^{1}$ & DB & 0.013 & 0.002 & 4717 & 0.510 & 0.007 & 0.001 & 4237 & 0.281 \\
\hline & $\mathrm{DC}$ & 0.015 & 0.005 & 1887 & 0.595 & 0.011 & 0.001 & 1588 & 0.424 \\
\hline By "automatic" adjustment & Yes & 0.022 & 0.003 & 2098 & 0.859 & 0.018 & 0.001 & 1867 & 0.693 \\
\hline & Yes/No & 0.021 & 0.004 & 1298 & 0.815 & 0.012 & 0.001 & 1090 & 0.469 \\
\hline & No & 0.005 & 0.004 & 3193 & 0.203 & 0.001 & 0.001 & 2855 & 0.043 \\
\hline
\end{tabular}

Note: ${ }^{1}$ “DC” = those who ever said they could adjust benefit or withdraw money; "DB” = all others. 
Table 4

"Long Differences"

Average Annual Increase between First and Last Pension Benefit

$(\Delta$ ln monthly benefit $) /(\Delta$ years $)$

matched to pension-generating jobs ${ }^{1}$

\begin{tabular}{|c|c|c|c|c|c|c|c|c|c|}
\hline & & \multicolumn{4}{|c|}{ All observations } & \multicolumn{4}{|c|}{$\mid \Delta \ln$ (pension)|>2 excluded } \\
\hline & Group & $\begin{array}{c}\text { Mean of } \\
\Delta \ln \text { pension } \\
\Delta \text { years }\end{array}$ & $\begin{array}{l}\text { Std. } \\
\text { Error }\end{array}$ & $\mathrm{N}$ & $\begin{array}{c}\text { Effective } \\
\text { Indexing } \\
\text { ratio }\end{array}$ & $\begin{array}{c}\text { Mean of } \\
\Delta \ln \text { pension } \\
\Delta \text { years }\end{array}$ & $\begin{array}{l}\text { Std. } \\
\text { Error }\end{array}$ & $\mathrm{N}$ & $\begin{array}{c}\text { Effective } \\
\text { Indexing } \\
\text { ratio }\end{array}$ \\
\hline All pensions matched to job & & 0.009 & 0.003 & 3688 & 0.328 & 0.007 & 0.001 & 3281 & 0.270 \\
\hline \multirow[t]{2}{*}{ By pension type ${ }^{2}$} & DB & 0.007 & 0.003 & 2570 & 0.284 & 0.006 & 0.001 & 2292 & 0.230 \\
\hline & $\mathrm{DC}$ & 0.005 & 0.008 & 471 & 0.202 & 0.008 & 0.002 & 412 & 0.304 \\
\hline \multirow[t]{3}{*}{ By industry } & Mfg. & -0.005 & 0.007 & 983 & -0.182 & -0.005 & 0.002 & 870 & -0.175 \\
\hline & PubAdm & 0.016 & 0.006 & 442 & 0.605 & 0.017 & 0.003 & 394 & 0.672 \\
\hline & Other & 0.012 & 0.003 & 2086 & 0.458 & 0.009 & 0.001 & 1868 & 0.350 \\
\hline \multirow[t]{2}{*}{ By union coverage } & Yes & 0.006 & 0.003 & 1132 & 0.246 & 0.004 & 0.001 & 1028 & 0.138 \\
\hline & No & 0.005 & 0.004 & 1017 & 0.183 & 0.007 & 0.001 & 911 & 0.257 \\
\hline \multirow[t]{2}{*}{ By pension type (SPD) ${ }^{3}$} & DB & 0.009 & 0.005 & 977 & 0.330 & 0.007 & 0.002 & 867 & 0.276 \\
\hline & $\mathrm{DC}$ & 0.007 & 0.006 & 893 & 0.271 & 0.008 & 0.002 & 802 & 0.291 \\
\hline & & & & & & & & & \\
\hline & & & & & & & & & \\
\hline & & & & & & & & & \\
\hline & & & & & & & & & \\
\hline
\end{tabular}

Note: ${ }^{1}$ Matched to longest job with pension coverage that ended no later than year in which benefits began.

${ }^{2}$ Based on respondent's last report of plan type

${ }^{3}$ Based on summary plan description from matched job 